\title{
Devlet Politikalarının Şirket Açıış ve Kapanışı Üzerindeki Etkileri: Türkiye İçin Ekonometrik Bir Analiz, 2010-2018
}

\section{Effects of Government Policies on Firm Openings and Closures: An Econometric Analysis for Turkey, 2010-2018}

\author{
Hakan Eryüzlü, a,"* Sertaç Hopoğlu ${ }^{\text {b }}$ \\ ${ }^{a}$ Dr. Öğr. Üyesi, İskenderun Teknik Üniversitesi, İşletme ve Yönetim Bilimleri Fakültesi, Ekonomi Bölümü, 31200, Hatay/Türkiye. \\ ORCID: 0000-0003-3715-0021 \\ b Dr. Öğr. Üyesi, İskenderun Teknik Üniversitesi, İşletme ve Yönetim Bilimleri Fakültesi, Uluslararası İşletmecilik ve Ticaret, 31200, Hatay/Türkiye. \\ ORCID: 0000-0002-9541-2352
}

\section{MAKALE BILLGİSİ}

\section{Makale Geçmiși:}

Başvuru tarihi: 07 Şubat 2019

Düzeltme tarihi: 01 Aralık 2019

Kabul tarihi: 06 Aralık 2019

\section{Anahtar Kelimeler:}

TAR Panel Testi,

Panel Birim Kök,

Şirket Açılışı,

Şirket Kapanışı

\section{ARTICLE INFO}

\section{Article history:}

Received 07 February 2019

Received in revised form 01 December 2019

Accepted 06 December 2019

\section{Keywords:}

TAR Panel Test

Panel Unit Root

Start-Ups

Firm Closures

\section{ÖZ}

Her ne kadar Dünya ekonomileri gün geçtikçe daha liberal politikalar ile ticareti şekillendirmeyi tercih etseler de devletlerin geliştirdikleri politikalar reel sektör üzerinde etki yaratmaktadır. Hiç kuşkusuz her devlet ülkesindeki şirket sayısının ve kapasitesinin artmasını ve mevcut şirketlerin ömürlerinin olabildiğince uzun olmasını arzu eder. Geliştirilen politikalarda bu arzuyu desteklemek yönündedir. Çalışmada 2010 Ocak - 2018 Aralık dönemlerini içeren analizde, Türkiye için açılan ve kapanan şirket sayıları 9 sektör özelinde incelenmiş ve durağanlıkları test edilmiştir. Sonuçlar Türkiye'de şirket açılış ve kapanışlarının genel anlamda durağan olduğu fakat kriz dönemlerinde yaşanacak şokların kalıcı olabileceğini göstermiştir.

\section{Giriş}

Reel sektörün en önemli kurumsal yapıları, küçük ve orta büyüklükteki işletmelerdir (KOBİler). Sadece birkaç ülkede değil tüm Dünyada KOBI'ler reel sektörün en önemli bölümünü oluşturmaktadır. Bu kadar önemli olmalarının nedenleri KOBİ'lerin ülke ekonomilerinde ihracat, istihdam, vergi vb. makro değişkenlere önemli katkılar sağlamalarıdır. Rakamlar incelendiğinde KOBİ'lerin önemi daha iyi anlaşılmaktadır; Tüm Dünyada şirketlerin ortalama \%95'i
KOBİ'lerden oluşurken Dünya istihdamının da ortalama \%40'1 KOBI'ler tarafından karşılanmaktadır. Teknolojinin gelişmesi sonucunda Dünya ticaretinde de değişimler yaşanmış ve esnek üretim yapabilen KOBİ tarzı şirketlerin tercih edilmesiyle, büyük çapta üretim yapan fakat hantal sayılabilecek Taylorist ve Fordist üretim modelleri terk edilmeye başlanmıştır. 1980 sonrası dönemde yaşanan krizlerde de KOBI'lerin değişim ve şoklara karşı daha esnek, ayrıca daha yaratıcı olduğu gözlemlenmiştir (Özdemir vd.,

* Sorumlu yazar/Corresponding author.

e-posta: hakan.eryuzlu@iste.edu.tr 
2007:178). Türkiye'de de Dünya ortalamalarına benzer istatistikler gözlenmektedir, Türkiye'de KOBİ ölçeğindeki şirketler, mevcut şirketlerin \%99'una yakınını oluşturmakta ve toplam istihdamın \%40'ını karşılamaktadır.

Büyük şirketler ise sayısal olarak KOBİ'lere göre çok daha az olmalarına rağmen, istihdam ve üretimin büyük kısmını karşılamaktadırlar. Aynı zamanda ülkelerin uluslararası alanda rekabet gücünün belirlenmesinde ve $\mathrm{Ar}-\mathrm{Ge}$ yatırımlarında öncü konumdadırlar. Türkiye'de mevcut tüm şirketler arasında büyük şirketlerin oranı yalnızca \%1 iken, büyük şirketler toplam istihdamın yaklaşık \%60'ını karşılamaktadırlar. Üretimin ise \%80’i yine büyük şirketler tarafindan yapılmaktadır.

Genel olarak şirket kuruluşunda ilk kurulacak şirketin büyük bir kuruluş olmasından ziyade KOBİ niteliğinde olması beklenen ve hatta istenen durumdur. Ekosistem içerisinde KOBİ'lerin yarattığı ekonomik istihdam, canlılık ve yenilikler yeni KOBI'lerin kurulmasını böylece girişimcilik faaliyetlerinde de KOBI'lerin başat bir faktör haline gelmesini sağlamaktadır. Bu sebepledir ki devlet teşvikleri KOBİ'lerin Ar-Ge içerikli, teknolojik odaklı şirketler olması için sürekli geliştirilmekte ve yeniden düzenlemektedir.

KOBI'lerin yukarıda bahsedilen avantajlarının aksi görüşlerde mevcuttur. KOBI'lerin önemi ve sektördeki yoğunlukları sebebiyle özellikle iktisadi kriz ortamlarında KOBİ'ler daha fazla etkilenmekte olduğu ve bu nedenle reel sektörde krizin etkilerinin şiddetli hissedilmesine sebep olduğu görüşünü destekleyici çalışmalar literatürde vardır; Emir ve Eyüboğlu (2010), çalışmalarında krizlerin KOBİ'ler üzerindeki etkilerini incelemiş ve kapanma, kapasite oranın düşmesi, ülke çapında sanayi üretim endeksinin azalması ve şirketlerin finansmanı konusunda KOBİ'lerin krizlerden etkilendiğini savunmuşlardır. Coşkun (2011), yaşanan küresel krizlerin KOBİ'ler üzerindeki etkilerini incelemiş ve gelişmiş ülkelerde sektöre yeni giren şirketlerin gelişmekte olan ülkelere göre daha az etkilendiğini tespit etmiştir.

KOBİ ya da büyük şirket fark etmeksizin şirketin açılışı, yaşam süresi ve kapanışları ülke ekonomisi adına son derece önemli aşamalardır. Devlet otoriteleri açısından istenilen durum, olabildiğince çok şirketin açılması ve şirketlerin yaşam sürelerinin olabildiğince uzun olmasıdır. Açılan her şirket piyasada rekabeti artıracak, üretimi arttıracak, mal ve hizmetlerin piyasada daha etkin bir şekilde sunulmasına ve en önemlisi istihdam yaratarak toplum refahın artmasına katkıda bulunacaktır. Yeni şirketlerin üretecekleri farklılaşmış ve yeni mal/hizmetlerle de hem ürün çeşitliliğini artırması, hem de yenilikçiliği ilerletmeleri bir diğer beklentidir. Ancak, şirketler de ekonomideki tüm birimler gibi ekonomik konjonktürde meydana gelen resesyon (kriz dönemi) ve refah dönemlerinden etkilenmektedirler. Yaşanan krizler ve refah dönemlerinin şirketler üzerinde yaratacağı etkilerin şirketlerin yaşam süreleri üzerine olumlu veya olumsuz yansımaları olacaktır. Örneğin, Ekşi (2010), KOBİ ve büyük ölçekli şirketlerin mali tablolarının kriz dönemindeki seyirlerini incelemiş ve kriz dönemlerinde her iki tip şirket türünün de olumsuz etkilendiği, kriz sonrası iktisadi ortamın iyileşme sürecinde de her iki tip şirket türünün iyileşme eğiliminde olduğunu tespit etmiştir. Türkiye ölçeğinde benzer çalışmalar da mevcuttur; Çoban v.d. (2010) Sivas ölçeğinde yaptıkları çalışmada, şirketlerin finansal tablolarından hareketle, 2008 krizinin etkilerini araştırmış ve kriz öncesi ile sonrası arasında ciddi farklılıklar tespit etmişlerdir. Coşkun (2011), çalışmasında da destekleyici sonuçlara Türkiye ölçeğinde ulaşmıştır. Sonuçlara göre, Türkiye'de açılan şirket sayısı, 2008 yılında bir önceki yıla göre \%11.3 azalmış ve 2009'da da bir önceki yıla göre \%9.9 azalmıştır. Coşkun (2011) ayrıca benzer azalış eğilimini ABD ve Avrupa'da da tespit etmiştir. Klapper ve Love (2011) da 93 ülkeden oluşan bir panelde mali krizin şirket açılışları üzerinde olumsuz etkisi olduğunu ve bu etkinin finans sektörü gelişmiş ülkelerde daha sert bir biçimde ortaya çıktığ 1 bildirmektedirler. Bu olumsuz etki özellikle kriz zamanlarında risk sermayesinin azalmasıyla ortaya çıkabildiği gibi (Block, De Vries ve Sandner, 2010), aynı zamanda yurtiçi ve yurtdışı talebin azalmasından da (Chowdhury, 2011) kaynaklanabilmektedir. Şirket kapanışlarının yanı sıra, işsizlik artışı, tüketici ve üretici güveninde düşüş, kapasite kullanım oranlarının azalması gibi birçok etkinin de Türkiye'de KOBI'lerin kriz döneminde yaşadığı olumsuz etkiler arasında olduğu bildirilmektedir (Aktürk, 2014). Diğer yandan, Simón-Moya v.d. (2016) kriz dönemlerinde girişimcilerin başka bir yerde iş bulamayacağından dolayı KOBİ'lerini kapatmalarının fırsat maliyetinin yüksek olduğunu, dolayısıyla kriz dönemlerinde KOBI'lerin hayatta kalma oranının yükseldiğini ileri sürmektedirler.

Hiç kuşkusuz şirketlerin açılışı ve yaşam sürelerini etkileyen birçok iç ve dış etken bulunmaktadır. Bu etkenlerden politika yapıcıların şirket açılışları ve şirketin devamını sağlama yönünde verdikleri destekler (girişimcilik destekleri, Ar-Ge destekleri, proje hibeleri, vergi afları vb.) çalışmanın ana konularındandır. Söz konusu devlet kaynaklı bu etkenler sürpriz olmayan ve yasalarla oluşturulan politikalar olduğundan, ekonomik aktörler tarafindan daha izlenebilir/kontrol edilebilir (şoklardan yani sürprizlerden uzak) etkenler olarak değerlendirilebilir.

Alınan politika kararları reel sektörü çeşitli kanallar vasıtasıyla etkiler. Örneğin girişimcilik desteği sonucu belli bir dönemde kaç şirket kurulduğu ya da resesyon dönemlerinde sağlanan vergi affından kaç şirketin yararlandığı, bu politikalar sonucunda ekonomik canlılığın durumu örnek verilebilir. Söz konusu bu politika süreci araştırmacılar açısından izlenebilir bir alan oluşturmaktadır. Söz gelimi, bir girişimcilik desteği sonucu kurulan şirketlerin sağladığı istihdam oranı politikanın başarı ölçütü olarak değerlendirilebilir. Şüphesiz, hükümetler aldıkları politika kararları ile şirket açılışlarını desteklemeyi ve yaşam sürelerini sürekli kılmayı hedeflerler. Fakat politikaların etkin olup olmadığı her zaman tartışma konusudur. Başarılı politikanın kıstası nedir? İstihdam mıdır, üretim midir veya başka özel kıstaslar mıdır? $\mathrm{Bu}$ araştırmada özellikle Türkiye'de özel sektör destek ve teşviklerinin arttığ 2010 Ocak sonrası dönem ile 2018 Aralık arasındaki dönemde, aylık olarak elde edilen verilerle hükümet politikalarının açılan ve kapanan şirketler üzerinde, iktisadi konjonktür içerisinde meydana gelen değişimler çerçevesinde, olumlu yönden etki edip etmediği (şirket açılışlarının artması ve kapanışlarının azalması) araştırılmıştır. Böylelikle söz konusu politikaların istenilen etkiye sahip olup olmadıkları, şirket açılış ve kapanış sayısı üzerinden tespit edilmeye çalışılmıştır. Bu kapsamda şirket açılışlarının artması ve kapanışlarının azalması devlet politikalarının başarılı olduğu yönünde tek başına değerlendirilmemiştir. Çalışmayı diğer çalışmalardan ayıran en önemli özellikte bu noktadır. Çalışmada Türkiye'de 9 sektör özelinde (imalat”, “tarım, 
ormancılık ve balıkçılık", "inşaat", "toptan ve perakende ticaret", "ulaştırma ve depolama", "konaklama ve yiyecek hizmeti faaliyetleri”, "bilgi ve iletişim", "insan sağlığı ve sosyal hizmet faaliyetleri" ve "eğitim" ) açılan ve kapanan şirket sayıları aylık olarak alınmış ve açılan şirketler ile kapanan şirketler panel serilerinde meydana gelen şokların kalıcılığı dönemler temelinde analiz edilmiştir. Genel bir ifadeyle şokların kalıcı olduğu (ekonometrik olarak birim köklü panellerde) durumda devlet politikaları etkisiz, tam tersi durumda etkili kabul edilmiştir.

Çalışma, giriş dâhil beş bölümden oluşmaktadır. 2. bölümde Türkiye'de özel sektör dahilindeki politikalara k1saca değinilmiş, 3. bölümde kullanılan veri seti ve metodoloji açıklanmış, 4. bölümde analiz sonucunda elde edilen ampirik sonuçlar gösterilmiş ve nihayet 5 . bölümde değerlendirme ve politika önerileri yapılmıştır.

\section{Türkiye’de Özel Sektör Destekleri}

Türkiye'de özel sektörün istenilen olgunluğa ulaşması için Cumhuriyet tarihi boyunca çeşitli araçlarla politikalar geliştirilmiştir. Kimi zaman devletin özel sektörle yatırım yapması, kimi zaman kredi ve teşviklerin sağlanması modern iktisadi hayata geçme çabaları içerisinde değerlendirilebilir. Özellikle 1960 sonrası planlı ekonomi dönemi ve 1980 sonrası yaşanan liberal dönüşüm iktisadi açıdan önemli gelişmelerdir. Ancak, Türkiye ekonomisinin en önemli özelliklerinden biri kriz durumlarındaki kırılganlığıdır. Sadece 1980 ve sonrası dönemde birçok krizin Türk ekonomisi üzerindeki olumsuz etkileri görülebilmektedir. Özellikle 1990 sonrası yaşanan yapısal ve finansal sorunlar enflasyon, kamu açığı ve cari açık ile birlikte cari açı̆̆ın finansmanı için borçlanmaya başvurulması krizlerin kronikleşmesine neden olan faktörlerdir. Daha sonrasında uygulanan istikrar politikalarında da birincil kaynak olarak borçlanmaya başvurulması krizlerin etkilerini uzatmaktan öteye geçememiştir. Krizler ise toplumsal anlamda büyük maliyetler yaratmıştır. Özellikle yakın tarihteki 1994, 2000 ve 2001 krizlerinde devlet politikalarının ne kadar önemli olduğu da bir kez daha anlaşılmıştır (Fırat ve Soylu, 2014:5).

Gerçekten de Türkiye'de Cumhuriyet kurulduğundan beri devlet öncülüğünde özel ve liberal sektörün gelişimi için birçok politika geliştirilmiştir. Özel sektöre hammadde sağlama ve yeni yatırımlar yapmasına destek olmak adına kurulan fabrikalardan, geliştirilen çeşitli dış ticaret politikalarından (özellikle korumacı), günümüzde uygulanan bölgesel kalkınma politikaları, girişimci destek programları, proje hibe destek programları, yatırım teşvikleri vb. gibi birçok politika sayılabilir. Aynı zamanda yine özel sektörü desteklemek ve onların yeteneklerini arttırmak amaçlarıyla; KOSGEB(Küçük ve Orta Ölçekli İşletmeleri Geliştirme ve Destekleme İdaresi Başkanlığı), kalkınma ajansları, teknokentler, organize sanayi bölgeleri gibi birçok kurumsal ve organizasyonel altyapı da devlet tarafindan oluşturulmaktadır.

Söz konusu durumlardan da anlaşılacağı gibi Türkiye gibi ülkelerde liberal piyasa istenilen olgunlukta olmadığından devlet politikaları bir kat daha önem kazanmaktadır. Bu durumda özel sektörü ilgilendirecek her politikanın sonucu daha keskin bir şekilde hissedilebilmektedir. Dünyada uygulanan çok çeşitli teşvik ve/veya destek politika örnekleri mevcuttur. Politikalar ülke ekonomilerine özgü özellikler taşısa da biraz farklılaştırılarak başka ülkelerde de uygulanabilir. Türkiye'de de uygulanan özellikle girişimciliği teşvik eden politikaların, diğer ülkelerdeki benzer politikalar ile karşılaştırıldığında değiştirilmesi gereken özellikleri bulunabilir. Diğer yandan, uygulanan politikalar değişik sektörlerde farklı sonuçlar doğurabilmektedir (Olcay ve Bulu, 2015). Yine de bu tip politikaların ülkede hâkim olan siyasi ideoloji ve makro göstergelerin yanı sıra risklerin etkileri ile oluşturulduğu bilinmelidir (Orki, 2015:69-70). Kriz zamanında KOBI'lerin hayatta kalması için uygulanan devlet politikaları genellikle KOBI'lerin mevcut (ve düşük düzeydeki) işletme sermayelerini korumaya ve akışkan finansmana erişimlerini artırmaya yönelik olmaktadır (OECD, 2009). Bu gibi politikalar genellikle vergi araçlarını (vergi indirimi veya muafiyeti) ve çeşitli geri ödemeleri içermekle birlikte, çeşitli sektörlerde yapılacak yatırımlar için devlet hibeleri ve hatta KOBİlere doğrudan nakit desteğini de içerebilmektedir (Visinescu ve Micuda, 2011). Literatürde genel olarak KOBI'ler için uygulanan finansa erişim, vergi uygulamaları ve yenilikçilik destekleri gibi politikaların KOBİ yaşam sürelerine etkilerini araştıran çalışmalar çoğunluktadır. Bununla birlikte, krizler ve şirket açılış-kapanışları ilişkisi birçok çalışmada veri olarak (genellikle krizin getirdiği şirket kapanışları olarak) alınmakta, ekonomideki şokların etkileri göz ard1 edilmektedir. Bu nedenle KOBİ politikalarının etkilerinin, ekonomideki değişimler de göz önüne alınarak sektörel olarak incelenmesi gelecekte yapılacak politikalara ışık tutacaktır.

\section{Metodoloji ve Veri Seti}

Çalışmada araştırma hipotezleri, TAR Panel ya da threshold birim kök testi olarak bilinen, panel eşikli birim kök testi ile sınanmıştır. Panel eşikli birim kök testi, paneli oluşturan kesitler arasındaki bağımlılığı dikkate alan ikinci kuşak bir panel birim kök testidir. Beyaert ve Camacho (2008) tarafından geliştirilen test, üç ana yaklaşımı dikkate almaktadır: panel için eşik bir değer belirlenmesi, eşik değerin ayırdığı her iki bölüm (rejimler) ve tamamı için ayrı ayrı birim kök testleri ve tüm sonuçların önyüklemeli (bootstrap) yöntem ile yapılması.

Beyaert ve Camacho (2008), çalışmalarında Evans ve Karras'1n panel veri ile yakınsamayı test etmek amaciyla geliştirdiği denklem (1)'i yakınsamanın tek tip olmadığını varsayarak denklem (2) olarak yeniden düzenlemişlerdir.

$\Delta g_{n, t}=\delta_{n}+\rho_{n} g_{n, t-1}+\sum_{i=1}^{p} \varphi_{n, i} \Delta g_{n, t-i}+\varepsilon_{n, t}$

Denklem (1)

$\Delta g_{n, t}=\left[\delta_{n}^{1}+\rho_{n}^{1} g_{n, t-1}+\sum_{i=1}^{p} \varphi_{n, i}^{1} \Delta g_{n, t-i}\right] I_{\left\{z_{t-1}<\lambda\right\}}+$ $\left[\delta_{n}^{2}+\rho_{n}^{2} g_{n, t-1}+\sum_{i=1}^{p} \varphi_{n, i}^{2} \Delta g_{n, t-i}\right] I_{\left\{z_{t-1} \geq \lambda\right\}}+\varepsilon_{n, t}$

Denklem (2)

Denklem (2)'de I $\{x\}, x$ doğru olduğunda 1 değerini, aksi takdirde 0 değerini alan bir göstergedir. $\mathrm{Bu}$ nedenle, eğer $z_{t-1}<\lambda$ koşulu yerine getirilirse birim değer alan değişken, kukla değişken olarak hareket eder. Yani, her halükarda, açılan/kapanan şirket sayısı dinamiği, iki olası rejimden birini izler. $z_{t-1}<\lambda$ ve "rejim II" ise, $z_{t-1} \geq \lambda$ olan durum "rejim I" olarak adlandırılır. Bu nedenle $\lambda$, bir "eşik" parametresidir ve denklem (2), öncelikle Chen (1978) 
tarafindan geliştirilen eşik otoregresif (TAR) modellerin sınıfına aittir. Denklem (2) 'de, p'nin yeterince yüksek olduğu varsayılsa $\mathrm{da}, \mathrm{t}$, her $\mathrm{n}$ için beyaz bir gürültü sürecidir ve sektörler arası korelasyon göz ardı edilemez. Ekonomik açıdan değerlendirildiğinde bu durum, şoklar serisel olarak ilişkisiz olsa da, yakınsak ülkelerin aynı türden şoklardan etkilenmesinin muhtemel olduğu şeklinde yorumlanır.

Denklem (2) tahmin edildiğinde, üstünlüğünün doğrusal Evans-Karras modeline (denklem (1)) göre kontrol edilmesi gerekir. Doğrulanırsa, bir sonraki aşama, denklem (2) 'nin $\rho$ katsayılarına bir tür birim kök testi uygulayarak, yakınsaklık olup olmadığının test edilmesinden ibarettir. Son olarak, yakınsama kanıtı varsa, son adım denklem (2) 'nin $\delta$ katsayılarının koşullu yakınsamaya karşı mutlak bir test ile sinanmasidir.

Tek denklemli bir TAR çerçevesinde, Hansen (1996) ve Caner ve Hansen (2001), önyükleme simülasyonları ile kritik değerler elde edilir. Sonraki aşamada da aşağıdaki hipotez test edilir;

$H_{o, 1}: \delta_{n}^{1}=\delta_{n}^{2}, \quad \rho_{n}^{1}=\rho_{n}^{2}, \quad \varphi_{i, n}^{1}=\varphi_{i, n}^{2}$

Hipotezlerde, $\mathrm{Vn}=1, \ldots, \mathrm{N}$ ve $\mathrm{Vi}=1, \ldots, \mathrm{p}$ iken tüm katsayıların her iki rejimde de eşit olmadığı için, denklem (1) FGLS ile denklem (2) ise grid-FGSL yöntemiyle tahmin edilir. Her bir model için, tahmin noktasında olabilirlik fonksiyonunun değeri hesaplanır ve $£ 12=-2 \ln (\mathrm{L} 1 / \mathrm{L} 2)$ değeri elde edilir. L1 denklem (1) için tek rejimli doğrusal model denklemidir ve L2 iki rejimli TAR modelinin gerçekleşme değeridir. Eğer $£ 12$ çok büyük ise; doğrusallığ 1 gösteren $\mathrm{H}_{0}$ hipotezi reddedilir. $\mathrm{Bu}$ büyüklüğün ne kadar olması gerektiği konusundaki kritik değerler de Caner ve Hansen'in (2001) çalışmalarından elde edilir. Tam bu noktada önyükleme yöntemi sonucunda, birim kök tespiti daha yapılmadığından, "kısıtlı" ve "kısıtsız" olmak üzere iki model elde edilir. İki modelinde doğrusallığı test edilir. Eğer iki modelde aynı anda doğrusal çıkmaz ise, panel TAR yöntemi uygulanabilir (denklem (2)'den devam edilir). Eğer modellerden biri ya da ikisi doğrusal çıkarsa, panel TAR yöntemi uygulanamaz (denklem (1)'den devam edilir). Denklem (2)'den devam edilmesi durumunda $\mathrm{H}_{0,2}$ hipotezi aşağıdaki şekildedir;

$H_{0,2}: \rho_{n}^{1}=\rho_{n}^{2}=0 \forall_{n}$

Hipotez (2)

Denklem (2)'nin geçerli olması ülke açısından, 2 farklı rejimin geçerli olduğunu gösterecektir. Bu rejimler eşik değeri ortaya çıkarken, rejim 1 söz konusu verinin eşik değerinin üstünde olduğu zamanları, rejim 2 ise tam tersi durumu gösterecektir. Yukarıda belirtildiği gibi test, üç ana yaklaşımı dikkate almaktadır: panel için eşik bir değer belirlenmesi, eşik değerin ayırdığı her iki bölüm (rejimler) ve tamamı için ayrı ayrı birim kök testleri. Bu üç durum aşağıdaki gibi test edilir:

$H_{A, 2 a}: \rho_{n}^{1}<0, \quad \rho_{n}^{2}<0 \forall_{n}$

Hipotez (2a)

$H_{A, 2 b}: \rho_{n}^{1}<0, \quad \rho_{n}^{2}<0 \forall_{n}$

Hipotez (2b)

$H_{A, 2 c}: \rho_{n}^{1}<0, \quad \rho_{n}^{2}<0 \forall_{n}$

Hipotez (2c)

Hipotez (2a), hem rejim 1 hem de 2 altındaki kesitlerin yakınsamasını yansıtmaktadır. Bu durum "tam yakınsama" olarak adlandırılır. Diğer hipotezler (2b) ve (2c) yakınsamaların sadece rejim 1 veya sadece rejim 2 altında gerçekleştiği anlamına gelir. Böyle bir durum "kısmi yakınsama" olarak adlandırılır. Boş değer ve alternatif hipotezin, r katsayılarının tüm kesitler için aynı özelliği belirli bir zamanda sağladığını varsayımı unutulmamalıdır.

Üç ana yaklaşımı birbirinden ayırmak için, Caner ve Hansen (2001)'nin çalışmalarından birkaç test istatistiği kullanılır. Caner ve Hansen (2001) önerdiği test istatistiği denklem (3)'te verilmiştir;

$R_{2}=t_{1}^{2}+t_{2}^{2}$

Denklem (3)

Buradaki $X, i=1$ ve Y için, model 1'deki Y'nin grid-FGLS tahminidir. Büyük $\mathrm{R}_{2}$ değerleri yakınsama için elverişlidir. Öte yandan, $t_{1}$ 'in çok küçük ve $t_{2}$ 'nin olmadığ 1 durumda, 1 . rejim (denklem (2)) altında yakınsama ve 2. rejim (denklem (1)) altında farklılaşma hipotezi reddedilemez ise, uygun olasılık değerlerini bulmak için, önyükleme kritik değerleri hesaplanır.

Yakınsama analizinin son adımı mutlak ve koşullu yakınsama arasında ayrım yapmaktan ibarettir. Ferreira ve Vieira (2009) tarafından önerilen hipotezler aşağıdaki gibidir;

$H_{0,3}: \delta_{n}^{i}=0, \quad \forall n$ ve $\forall i$

Hipotez (3)

$H_{A, 3 a}: \delta_{n}^{i} \neq 0$

Hipotez (3a)

$H_{A, 3 b}: \delta_{n}^{1}=0, \quad \delta_{n}^{2} \neq 0$

Hipotez (3b)

$H_{A, 3 c}: \delta_{n}^{1} \neq 0, \quad \delta_{n}^{2}=0$

Hipotez (3c)

Ana hipotez altında $\rho_{n}^{i}<0, \forall n, H_{0,3}$, her iki rejim altında mutlak yakınsamayı gösterir ve $H_{A, 3 a}$ 'daki alternatif ise şartlı yakınsamayı etkiler. Alternatif hipotezler $H_{A, 3 b}$ ve $H_{A, 3 c}$, birinci ve ikinci rejimlerde koşullu yakınsama ve sırasıyla ikinci ve birinci rejimlerde mutlak yakınsama anlamına gelir. Beyaert ve Camacho (2008)'nun $\emptyset_{j}, j=a, b, c$ testleri kullanılarak boş hipotez test edilir. Kritik değerler önyükleme simülasyonları ile elde edilir (Yavuz ve Yılancı, 2013: 288).

Çalışmada Türkiye Odalar ve Borsalar Birliği (TOBB) veri tabanından elde edilen açılan ve kapanan şirket sayıları verileri kullanılmıştır. Fakat söz konusu şirket sayıları çalışmanın hassasiyetini arttırmak amacıyla farklı bir veri seti şeklinde tasnif edilmiştir. Çalışma kapsamında 9 sektör belirlenmiştir; "imalat", "tarım, ormancılık ve balıkçılık", "inşaat", "toptan ve perakende ticaret", "ulaştırma ve depolama", "konaklama ve yiyecek hizmeti faaliyetleri", "bilgi ve iletişim", “insan sağlığı ve sosyal hizmet faaliyetleri" ve "eğitim" sektörleri. Söz konusu sektörler en çok hareketliliğin ve istihdam alanlarının bulunduğu sektörlerdir. Her bir sektör için 2010 Ocak - 2018 Aralık arası döneme ait aylık açılan ve kapanan şirket sayıları TOBB veri tabanından alınmıştır. Daha sonra açılan ve kapanan şirketler ayrı ayrı iki panel halinde düzenlenmiştir. Buna göre bir panelde (açılan veya kapanan şirket olarak) 9 sektör dikey kesitlerde (sütunda), 108 aylık veri yatay kesitlerde(satır) bulunmaktadır. Genelleştirilmiş bir benzetim ile standart bir panelde yer alan ülkeler yerine veri setinde sektörler yer almaktadır.

Şirket sayılarında sadece TOBB'a kayıt olan şirketlerin alınmasının sebebi, ülke ekonomisinin neredeyse tamamını temsil edebilecek nitelikte olan KOBİ, büyük şirket vb. şirketlerin TOBB şemsiyesi altındaki odalara kayıt zorunluluğudur. Kanunen de bu zorunluk belirlenmiştir. 5174 sayılı Kanunun 9 uncu Maddesine göre: "Ticaret 
siciline kayıtlı tacirler ve 5 inci Maddeye göre sanayici ve deniz taciri sıfatını haiz tüm gerçek ve tüzel kişiler ile bunların şubeleri ve fabrikaları, bulundukları yerdeki odaya kaydolmak zorundadır. Meslek gruplarına göre yapılacak üye kayıtları, elektronik ortamda Bakanlık ve Birlik bünyesinde düzenlenen ortak veri tabanında güncel olarak tutulmaktadır" (Resmi Gazete, 2004:8774). Daha teknik bir ifade ile, ticaret sicil kayıt zorunluluğu bulunan şirketler TOBB kuruluşlarına kayıt olmalıdır.

\section{Ampirik Analiz}

Çalışmada 9 sektör üzerindeki analiz, tüm sektörleri temsil edecek iki panele ayrılarak yapılmıştır. Bunlardan ilki 9 sektör için açılan şirket sayıları (2010 Ocak - 2018 Aralık arası) ve 9 sektör için kapanan şirket sayıları (2010 Ocak 2018 Aralık arası). Her bir panel ayrı ayrı, panel TAR ya da threshold birim kök testi olarak bilinen, panel eşikli birim kök testi ile sınanmıştır. Panel eşikli birim kök testi, paneli oluşturan kesitler arasındaki durağanlığı dikkate alan ikinci kuşak bir panel birim kök testidir.

Araştırılan hipotez; “devlet politikaları, şirket açılış ve kapanış üzerinde olumlu etkiye sahiptir" yani devlet politikaları şirket açılışlarını destekler ve kapanışlarının önüne geçmeye çalışır hipotezidir. Bu hipotezi test etmek amacı ile kullanılan panel eşikli birim kök testi de paneli "durgunluk" ve "refah" dönemi olarak dikkate almakta ve rejim olarak nitelendirdiği bu dönemleri birleştiren bir fonksiyon kullanmaktadır. Böylece bir panelin durağan çıkması ya da çıkmaması; devlet politikalarının o panel seti üzerinde, hangi dönemlerde (durgunluk ya da refah) etkili olduğu veya olmadığı hakkında bilgi verecektir.

Öncelikle 9 sektör için ("imalat", "tarım, ormancılık ve balıkçılık", "inşaat", "toptan ve perakende ticaret", "ulaştırma ve depolama", "konaklama ve yiyecek hizmeti faaliyetleri", "bilgi ve iletişim", "insan sağlığı ve sosyal hizmet faaliyetleri" ve "eğitim" ) oluşturulan panelin durağanlığı, panel eşikli birim kök testi ile test edilmiştir.

Açılan şirket sayıları analizinde, Panel TAR yöntemiyle belirlenen eşik değerinin üstünde kalan değerlerin bulunduğu birinci rejim genel olarak değerleri yüksek verilerin bulunduğu rejimdir. Bu bakımdan analizde birinci rejim genellikle (seriye göre değişebilmektedir) refah dönemini temsil ederken, belirlenen eşik değerinin altında kalan değerlerin bulunduğu ikinci rejim çoğunlukla değerleri düşük verilerin bulunduğu rejim olduğundan genellikle durgunluk dönemini temsil etmektedir. Analizde 10.000 önyükleme (bootstrap) kullanılmıştır.

Açılan şirket için hesaplanan eşik değeri tablo 1'deki gibidir;

Tablo 1. Eşik Değer Sonuçları

\begin{tabular}{l|l}
\multicolumn{1}{c}{ Hesaplanan } & \multicolumn{1}{c}{ Değer } \\
\hline Eşik Değeri & 323,000 \\
1. Rejimde gözlem yüzdesi & 86,585
\end{tabular}

Eşik değeri 323 olarak hesaplanmıştır. Test bu eşik değerinin üstündeki değerleri birinci rejime (refah dönemi) altındaki değerleri ise, ikinci rejime (durgunluk) atamıştır. Sonuçlara göre değerlerin \%86.54'ü eşik değerinin üstünde, \%13.46's1 ise altındadır.
TAR Panel yöntemine devam edebilmek için, sistemin doğrusal olmaması gerekmektedir. Açılan şirket için hesaplanan doğrusallık test sonuçları Tablo 2'deki gibidir;

Tablo 2. Doğrusallık Sonuçları

\begin{tabular}{l|l}
\multicolumn{1}{c}{ Hesaplanan } & P-Değeri \\
\hline K1sıtsız Önyüklemeli & 0.0040 \\
Kısıtlı Önyüklemeli & 0.0040
\end{tabular}

Sonuçlara göre panelin doğrusal olduğunu savunan $\mathrm{H}_{0}$ hipotezi reddedilmiştir. Panel doğrusal çıkmadığından TAR Panel yöntemi ile uygulamaya devam edilebilir. Sirada rejimlerin birim kök testleri var. Rejimlerin birim kök testi sonuçları Tablo 3'de verilmiştir.

Tablo 3. Birim Kök Testi Sonuçları

\begin{tabular}{l|l}
\multicolumn{1}{c}{ Hesaplanan } & P-Değeri \\
\hline Rejim 1 & 0.0019 \\
Rejim 2 & 0.0156 \\
Rejim 1 ve 2 beraber & 0.0016
\end{tabular}

Birim kök testlerinde $\mathrm{H}_{0}$ panelin eşikli birim köklü olduğunu, alternatif hipotez ise, panelin durağan olduğunu savunmaktadır. Tablo 3'e göre birinci rejim (refahı temsilen) durağan, ikinci rejim(durgunluğu temsilen) ise, $\% 1$ anlamlılık düzeyinde durağan değildir. Rejimler beraber değerlendirildiğinde ise, panel durağan çıkmaktadır.

Kapanan şirket sayıları analizinde, Panel TAR yöntemiyle belirlenen eşik değerinin üstünde kalan değerlerin bulunduğu birinci rejim genel olarak değerleri yüksek verilerin bulunduğu rejimdir. Bu bakımdan analizde birinci rejim, açılan şirket sayılarının aksine, durgunluk dönemini temsil ederken, belirlenen eşik değerinin altında kalan değerlerin bulunduğu ikinci rejim genel olarak değerleri düşük verilerin bulunduğu rejim olduğundan, açılan şirket sayılarının aksine, refah dönemini temsil etmektedir. Analizde 10.000 önyükleme (bootstrap) kullanılmıştır.

Kapanan şirket için hesaplanan eşik değeri Tablo 4'deki gibidir;

Tablo 4. Eşik Değer Sonuçları

\begin{tabular}{l|l}
\multicolumn{1}{c}{ Hesaplanan } & \multicolumn{1}{c}{ Değer } \\
\hline Eşik Değeri & $-11,000$ \\
1. Rejimde gözlem yüzdesi & 22,115
\end{tabular}

Eşik değeri $-11,000$ olarak hesaplanmıştır. Test bu eşik değerinin üstündeki değerleri birinci rejime (durgunluk dönemi) altındaki değerleri ise, ikinci rejime (refah) atamıştır. Sonuçlara göre değerlerin \%22.12'si eşik değerinin üstünde, $\% 77.88$ 'i ise altındadır.

TAR Panel yöntemine devam edebilmek için, sistemin doğrusal olmaması gerekmektedir. Kapanan şirket için hesaplanan doğrusallık test sonuçları Tablo 5'deki gibidir;

Tablo 5. Doğrusallık Sonuçları

\begin{tabular}{l|c}
\multicolumn{1}{c}{ Hesaplanan } & P-Değeri \\
\hline Kısıtsız Önyüklemeli & 0.0000 \\
Kısıtlı Önyüklemeli & 0.0000
\end{tabular}


Sonuçlara göre panelin doğrusal olduğunu savunan $\mathrm{H}_{0}$ hipotezi reddedilmiştir. Panel doğrusal çıkmadığından TAR Panel yöntemi ile uygulamaya devam edilebilir. Surada rejimlerin birim kök testleri var. Rejimlerin birim kök testi sonuçları Tablo 6'da verilmiştir.

Tablo 6. Birim Kök Testi Sonuçları

\begin{tabular}{l|l}
\multicolumn{1}{c}{ Hesaplanan } & P-Değeri \\
\hline Rejim 1 & 0.0238 \\
Rejim 2 & 0.0000 \\
Rejim 1 ve 2 beraber & 0.0000
\end{tabular}

Birim kök testlerinde $\mathrm{H}_{0}$ panelin eşikli birim köklü olduğunu, alternatif hipotez ise, panelin durağan olduğunu savunmaktadır. Tablo 6'ya göre birinci rejim (durgunluğu temsilen) \%1 anlamlılık düzeyinde durağan değildir. İkinci rejim (refahı temsilen) ise, durağan çıkmıştır. Rejimler beraber değerlendirildiğinde ise, panel durağan olmaktadır.

\section{Sonuçlar ve Değerlendirme}

Modern ekonomi anlayışı içerisinde ülke ekonomilerinin gün geçtikçe liberalleşiyor olmasına rağmen devletlerin aldıkları kararlar reel sektör üzerinde etkiler yaratmaya devam etmektedir. Hiç kuşkusuz her devlet ülkesindeki şirket sayısının ve kapasitesinin artmasını, mevcut şirketlerinde yaşam sürelerinin olabildiğince uzun olmasını arzu eder. Geliştirilen politikalar da yeni şirketlerin açılması ve mevcutlarında hayatta kalmasını desteklemek yönündedir.

$\mathrm{Bu}$ çalışmada Türkiye'de uygulanan devlet politikalarının şirketlerin açılması ve kapanması üzerindeki etkileri araştırılmıştır. Bu amaçla araştırma hipotezi olarak; "devlet politikaları, şirket açılışları ve kapanışları üzerinde olumlu etkiye sahiptir" yani devlet politikaları şirket açılışlarını destekler ve kapanışlarının önüne geçmeye çalışır hipotezi test edilmiştir. Test için, çalışmada Türkiye Odalar ve Borsalar Birliği (TOBB) veri tabanından elde edilen açılan ve kapanan şirket sayıları verileri kullanılmıştır.

Çalışmada araştırma hipotezleri, TAR Panel ya da threshold birim kök testi olarak bilinen, panel eşikli birim kök testi ile sınanmıştır. Panel eşikli birim kök testi, paneli oluşturan kesitler arasındaki bağımlılığı dikkate alan ikinci kuşak bir panel birim kök testidir. Beyaert ve Camacho (2008) tarafından geliştirilen test, üç ana yaklaşımı dikkate almaktadır: panel için eşik bir değer belirlenmesi, eşik değerin ayırdığı her iki bölüm (rejimler) ve tamamı için ayrı ayrı birim kök testleri ve tüm sonuçların önyüklemeli (bootstrap) yöntem ile yapılması.

Ampirik analiz sonuçları değerlendirildiğinde Türkiye önemli sonuçlar elde edilmiştir. Çıkan sonuçlar; Tablo 7'de özetlenmiştir;
Tablo 7. Ampirik Sonuçlar

Açılan Şirket

\begin{tabular}{|c|cc}
\hline Dönem & Sonuç & $\begin{array}{c}\text { Anlamlılık } \\
\text { Düzeyi }\end{array}$ \\
\hline $\begin{array}{c}\text { Refah Dönemi } \\
\text { Durgunluk } \\
\text { Dönemi } \\
\text { Tüm Panel }\end{array}$ & Durağan & 0.01 \\
& Dirim Köklü & 0.01 \\
\hline Dönem & Kapană Şirket & 0.01 \\
\hline Refah Dönemi & Sonuç & $\begin{array}{c}\text { Anlamlılık } \\
\text { Düzeyi }\end{array}$ \\
Durgunluk & Durağan & 0.01 \\
Dönemi & Birim Köklü & 0.01 \\
Tüm Panel & Durağan & 0.01 \\
\hline
\end{tabular}

Sonuçlar açılan ve kapanan şirketler açısından değerlendirildiğinde, açılan şirketler açısından;

- Panel bütünüyle incelendiğinde durağan olduğu için, devlet politikaları şirket açılışlarını olumlu yönde desteklemektedir. Yani Türkiye'de şirket açılışında meydana gelen şoklar kalıcı değildir.

- Rejimler (dönemler) ayrı ayrı incelendiğinde;

○ Refah dönemlerinde, şirket açılışlarında meydana gelen şoklar kalıcı değildir ve devlet politikaları bu dönemde istenilen etkiyi gösterebilmektedir.

○ Durgunluk dönemlerinde ise; \%1 anlamlılık düzeyinde şoklar kalıcı özellikler göstermektedir. Yani devlet politikaları şirket açılışı trendinin düşüşüne engel olamamaktadır. Fakat aynı sonuç, $\% 5$ ve $\% 10$ anlamlılık düzeylerinde durağan çıkmaktadır. $\mathrm{Bu}$ bakımdan, durgunluk dönemi için çok hassas dönemlerde (krizlerin büyük olduğu) devlet politikaları açılan şirket sayısı üzerinde olumlu etkiye sahip değildir yada politikalar yeterli düzeyde değildir yorumu yapılabilir.

Kapanan şirket açısından bakıldığında ise;

- Panel bütünüyle incelendiğinde durağan olduğundan, devlet politikaları şirket kapanışlarını olumlu yönde desteklemektedir. Yani, Türkiye'de şirket kapanışında meydana gelen şoklar kalıcı değildir. Devlet politikaları şirketlerin sürekliliğini destekler niteliktedir.

- Rejimler (dönemler) ayrı ayrı incelendiğinde;

○ Refah dönemlerinde, şirket kapanışlarında meydana gelen şoklar kalıcı değildir ve devlet politikaları bu dönemde istenilen etkiyi gösterebilmektedir.

○ Durgunluk dönemlerinde ise; \%1 anlamlılık düzeyinde şoklar kalıcı özellikler göstermektedir. Yani devlet politikaları şirket kapanışı trendinin yükselişine engel olamamaktadır. Fakat aynı sonuç, $\% 5$ ve $\% 10$ anlamlılık düzeylerinde durağan çıkmaktadır. Bu bakımdan, durgunluk dönemi için çok hassas dönemlerde (krizlerin büyük olduğu) devlet 
politikaları kapanan şirket sayısı üzerinde olumlu etkiye sahip değildir yorumu yapılabilir.

Türkiye için yapılan bu analiz göstermektedir ki, 2010 yılından 2018 yılı sonuna kadar, Türkiye'de açılan ve kapanan şirket sayıları genel anlamda durağandır. Yani devlet tarafindan her ne politika yapılıyorsa şirket açılış ve kapanışları düzenli bir seyir seyretmektedir. Arada bir şoklar meydana gelse de bu şoklar kalıcı değildir. Fakat analizin biraz daha detaylı boyutu durgunluk dönemlerinde meydana gelen şokların kalıcı olduğunu göstermektedir. Bu durumda özellikle krizlerin yoğun hissedildiği dönemlerde Türkiye'de şirket açılışlarının azalmaması ve kapanışlarının da artmaması için daha fazla önlem alınması gerekebilecektir. Gelecek araştırmalar için söz konusu kriz dönemlerinde uygulanan politikaların ne olduğu ve ne olması gerektiği araştırılabilir. Böylece çalışma daha özel bir alana yayılmış olacaktır.

\section{Kaynakça}

Aktürk, O. (2014). Impact of the Economic Crisis on SMEs (Small and Medium-Sized Enterprises): A General Evaluation on SMEs in Turkey. European Journal of Social Science Education and Research, 1(1), 169173.

Beyaert, A., \& Camacho, M. (2008). TAR panel unit root tests and real convergence. Review of Development Economics, 12(3), 668-681.

Block, J.H., De Vries, G.\& Sandner, P.G. (2010). Venture capital and the financial crisis: an empirical study across industries and countries, in D. Cummings. The Oxford Handbook of Venture Capital, 37-61.

Caner, M., \& Hansen, B. E. (2001). Threshold autoregression with a unit root. Econometrica, 69(6), 1555-1596.

Chen, C. H. (1978). Pattern recognition and signal processing. Problemy Sluchainogo Poiska, 1-24.

Chowdhury, S.R. (2011). Impact of Global Crisis on Small and Medium Enterprises. Global Business Review, 12(3), 377-399.

Coşkun, A. (2011). Küresel Krizin Girişimcilik Üzerine Etkisi: Piyasaya Yeni Giren Firmalar Açısından Ülke Karşılaştırması. Sosyal Bilimler Dergisi, 2(1), 128134.

Çoban, O., Akar, Ö. G. G., Akar, A. G. T., \& Karagöz, H. (2010). 2008 Küresel Finansal Krizinin Türkiye Ve Konya Ekonomileri Üzerine Etkileri, 1-26. http://teacongress.org/papers2012/COBAN-AKARAKAR-KARAGOZ.pdf.

Ekşi, İ. H. (2010). Firmaların Ölçekleriyle Krizden Etkilenme Düzeylerinin Karşılaştırılması: Tekstil Sektörü Örneği. Atatürk Üniversitesi İktisadi Ve İdari Bilimler Dergisi, 24(4), 65-78.

Emir, M., \& Eyüboglu, K. (2010). Global Finansal Krizin Türkiye'deki Kobiler Üzerindeki Etkileri. Muhasebe ve Finansman Dergisi, (46), 31-43.
Evans, P., \& Karras, G. (1996). Convergence revisited. Journal of monetary economics, 37(2), 249-265.

Ferreira, R. T., \& Vieira, G. C. (2009). Clubes de Convergência de Renda na América: uma Abordagem através de Painel Dinâmico Nãolinear. XXXVII Encontro Nacional de Economia da ANPEC, Foz do Iguaçu. 0-17 http://www.anpec.org.br/encontro2009/inscricao.on/ arquivos/000e287725689cd2c9d74658422ab604271.pdf

Firat, F. K., \& Soyu, E. (2014). Küresel krizin Türkiye'deki inşaat sektörü üzerindeki etkileri. In International Conference On Eurasian Economies, 525-532.

Hansen, B. E. (1996). Inference when a nuisance parameter is not identified under the null hypothesis. Econometrica: Journal of the econometric society, 2(64), 413-430.

Klapper, L. \& Love, I. (2011). The impact of the financial crisis on new firm registration. Economics Letters, 113(1), 1-4.

OECD (2009). The Impact of the Global Crisis on SME and Entrepreneurship Financing and Policy Responses, Contribution to the OECD Strategic Response to the Financial and Economic Crisis, OECD Centre for Entrepreneurship, SMEs and Local Development, 2009.

Olcay, G.A. \& Bulu, M. (2015). Who should really get government support: an analysis of Turkish SME cases. International Journal of Knowledge-Based Development, 6(1), 34-49.

Örki, A. (2015) 2015 Yılı Türkiye Girişimcilik Teşvik Ve Politikaları Karşılaştırmalı İncelemesi. Recep Tayyip Erdoğan Üniversitesi Sosyal Bilimler Dergisi, 2(4), 67-92.

Özdemir, S., Ersöz, H., \& Sarığlu, H. (2007). Küçük Girişimciliğin Artan Önemi ve KOBİ'lerin Türkiye Ekonomisindeki Yeri. Sosyal Siyaset Konferanslar Dergisi, 1(53), 173-230.

Simón-Moya, V., Revuelto-Taboada, L. \& Ribeiro-Soriano, D. (2016) Influence of economic crisis on new SME survival: reality or fiction? Entrepreneurship \& Regional Development, 28(1/2), 157-176.

Türkiye Odalar ve Borsalar Birliği İle Oda ve Borsa Kanunu (01.Haziran.2004). Resmi Gazete, 5174/25479.

Visinescu, S. \& Micuda, D. (2011). Romanian SME's sector trough crisis: the effectiveness of government policies and the present situation, MPRA Paper 30618, University Library of Munich, Germany. https://ideas.repec.org/p/pra/mprapa/30618.html.

Yavuz, N. C., \& Yilanci, V. (2013). Convergence in per capita carbon dioxide emissions among G7 countries: a TAR panel unit root approach. Environmental and Resource Economics, 54(2), 283-29 